\title{
THE
}

\section{In the Driver's Seat: Rico and Education}

Robert M. Rauber

Haiwei Shen

University of Rhode Island

et al

Follow this and additional works at: https://digitalcommons.uri.edu/gsofacpubs

\section{Citation/Publisher Attribution}

Rauber, R. M., Stevens, B., Davison, J., Goke, S., Mayol-Bracero, O. L., Rogers, D., Zuidema, P.,...Zawislak, J. (2007). In the Driver's Seat: Rico and Education. BAMS, 88, 1929-1938. doi: 10.1175/BAMS-88-12-1929 Available at: https://doi.org/10.1175/BAMS-88-12-1929

This Article is brought to you for free and open access by the Graduate School of Oceanography at DigitalCommons@URI. It has been accepted for inclusion in Graduate School of Oceanography Faculty Publications by an authorized administrator of DigitalCommons@URI. For more information, please contact digitalcommons-group@uri.edu. 


\section{IN THE DRIVER'S SEAT Rico and Education}

by Robert M. Rauber, Bjorn Stevens, Jennifer Davison, Sabine Göke,* Olga L. Mayol-Bracero, David Rogers, Paquita Zuidema, Harry T. Ochs III, Charles Knight, Jorgen Jensen, Sarah Bereznicki, Simona Bordoni, Humberto Caro-Gautier, Marilé Colón-Robles, Maylissa Deliz, Shaunna Donaher, Virendra Ghate, Ela Grzeszczak, Colleen Henry, Anne Marie Hertel, Ieng Jo, Michael Kruk, Jason Lowenstein, Judith Malley, Brian Medeiros, Yarilis Méndez-Lopez, Subhashree Mishra, Flavia Morales-Garcia, louise A. Nuijens, Dennis O'Donnell, Diana L. Ortiz-Montalvo, Kristen Rasmussen, Erin Riepe, Sarah Scalia, Efthymios Serpetzoglou, Haiwei Shen, Michael Siedsma, Jennifer Small, Eric Snodgrass, Panu Trivej, and Jonathan Zawislak

RICO carried out a wide array of educational activities, including a major first in a field projecta complete mission executed entirely by students.

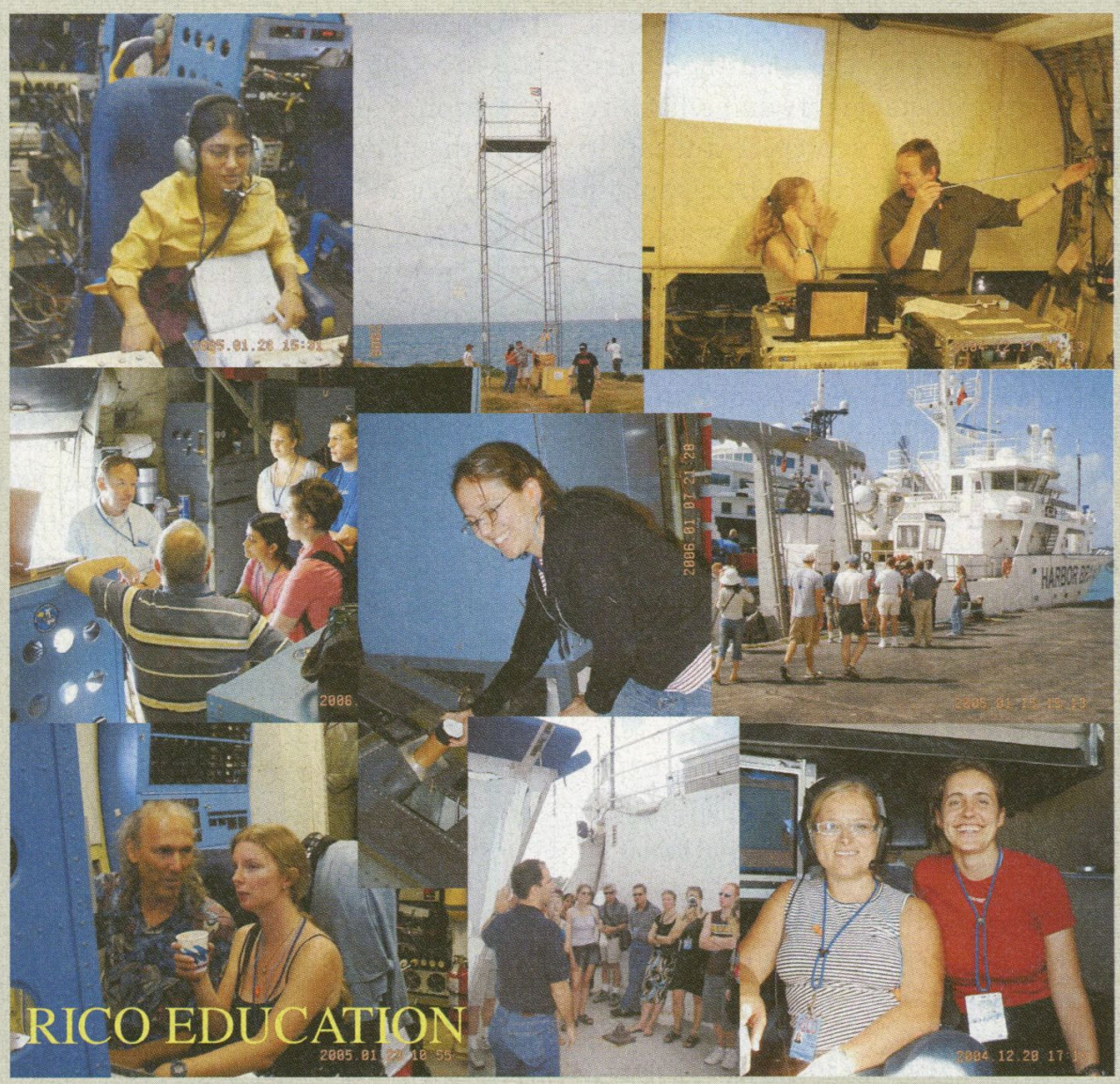

M any of the best and brightest scientists in our field were drawn into atmospheric sciences through field work. From the Thunderstorm Project of the 1940s to the modern campaigns of today, atmospheric science has a long tradition of involving students in field campaigns. For example, many special efforts have been made to integrate airborne research with classroom learning. The
National Center for Atmospheric Research (NCAR) Research Aviation Facility, for example, has successfully involved students in research flights as part of a course (Hallett et al. 1990) and in flights designed primarily for tests of new instrumentation (Stith and Rogers 2004). Graduate students at McGill University have designed and carried out flights using the University of Wyoming King Air as part of 
a National Science Foundation educational initiative to promote field education (Fabry et al. 1995). Groundbased facilities, such as Storm Peak Laboratory in western Colorado and the Colorado State University CSU-CHILL radar, have also become centers of student learning concerning field measurements (Hallett et al. 1993; Borys and Wetzel 1997; Wetzel et al. 2003).

In this great tradition, the organizers of the Rain in Cumulus over the Ocean (RICO) field campaign committed to providing a unique array of educational opportunities for graduate and undergraduate students. The RICO education program was designed to avoid the tendency for field work to mire students in often monotonous tasks. Rather, we worked to ensure that the students developed both an understanding of RICO's scientific objectives and a personal stake in achieving those objectives. Our immediate goals were to educate students about field measurements, the science underlying their use, and the efforts scientists take to ensure data quality and reliability. In the long term, the goal was to prepare students to become effective organizers of and participants in future large field experiments, because those are skills that cannot be acquired easily except by experience, and opportunities are relatively limited.

With support through research grants from the National Science Foundation (NSF) and the NSF Research Experience for Undergraduate program, 24 graduate and 9 undergraduate students experienced a wide variety of educational activities, including training sessions at the facilities, in-field seminars, and hands-on experience with all of the major instrumentation platforms, including the project aircraft. These experiences culminated in a major first for a field campaign - a complete scientific mission, including research flights, planned and executed entirely by students.

This article summarizes the educational component of RICO, with the hope that RICO will serve as a template for integration of education into field campaigns of the future.

\section{FLYING HIGH-THE C-I30 AND KING AIR}

MISSIONS. Students participating in RICO were challenged to organize and prepare a proposal to carry out a scientific mission using the major platforms of the campaign. The requirements were that the proposed research should be novel, scientifically sound, and technologically possible, and should fit within the overall goals of RICO, which focused on both the formation of rain in shallow cumuli and how rain modifies the structure and ensemble statistics of trade wind clouds (Rauber et al. 2007). The proposal was to be submitted to the project organizers during the second half of the field campaign, in mid-January, after the students had time to work with the facilities and meet and debate possible options. The January time frame was also optimal for maximum student participation, since students are on holiday break. If the proposed research met the criteria, the students would be given an opportunity to present their proposal during a project science meeting, where project scientists could ask questions and make recommendations. The students also had to write an operation plan and determine field responsibilities. After the presentation, the project organizers would decide if the students would be allocated time to carry out the mission. If given a green light, on a suitable day late in the campaign they would be
AfFiliations: Rauber, Davison, Goke, Ochs, Colón-Robles, Hertel, KrUK, RiePE, SCALIA, AND SnOdgrass-University of Illinois at Urbana-Champaign, Urbana, Illinois; Stevens, Bordoni, Medeiros, AND TRIVEj-University of California, Los Angeles, Los Angeles, California; Mayol-Bracero, Caro-Gautier, Deliz, Méndez-Lopez, Morales-Garcia, and Ortiz-Montalvo-University of Puerto RicoRío Piedras, San Juan, Puerto Rico; Rogers, KNIGHT, AND JensenNational Center for Atmospheric Research, Boulder, Colorado; Zuidema, Donaher, Ghate, Jo, Rasmussen, and SerpetzoglouUniversity of Miami, Miami, Florida; Bereznicki AND Henry-Purdue University, West Lafayette, Indiana; GrzeszCZAK - Warsaw University, Warsaw, Poland; LOWENSTEIN-University of Leeds, Leeds, United Kingdom; Maller-Clague Middle School, Ann Arbor, Michigan; MiSHRA-Desert Research Institute, University of Nevada, Reno, Nevada; NuIJENS-Wageningen University and Research Centre, Wageningen, Netherlands; O'DONNELL-University of Wyoming, Laramie, Wyoming; SHEN-University of Rhode Island,
Kingston, Rhode Island; SIEDSMA-U.S. Naval Academy, Annapolis, Maryland; SMALL-University of California at Santa Cruz, Santa Cruz, California; KRUK-Illinois State Water Survey, Champaign, Illinois; ZaWISLAK-The Pennsylvania State University, University Park, Pennsylvania

*CURRENT AFFILIATION: University of Helsinki, Helsinki, Finland CORRESPONDING AUTHOR: Robert M. Rauber, Department of Atmospheric Sciences, University of Illinois at Urbana-Champaign, 105 S. Gregory St., Urbana, IL 6180 I

E-mail: rauber@atmos.uiuc.edu

The abstract for this article can be found in this issue, following the table of contents.

DOI:10.1175/BAMS-88-12-1929

In final form 19 June 2007

(C)2007 American Meteorological Society 
given control of the facilities in order to carry out the mission. The data collected would be available for future analyses.

Soon after the January phase of the field campaign began, the students met and presented ideas to each other for the research mission. Meetings were lively and debates were vigorous, which is typical of planning meetings of project scientists. From their meetings three proposals emerged, with different groups of students committed to each mission. The students believed that carrying out the three missions was possible within the 8 -h time frame of a typical C-130 mission. The three missions were as follows:

1) Cloud processing of aerosols: The students wanted to determine if aerosol modification by clouds was significant enough to affect the downshear aerosol distribution in the trade wind layer, changing the environment for subsequent cloud growth. The proposed flight plan differed from other RICO flights in that it required sampling a cloud line and its environment at several altitudes in an along-line pattern, upshear at low levels, within the clouds at several levels, and downshear in the detrained outflow near the top of the clouds. The King Air flight plan would support this scientific mission by sampling the precipitation structure of nearby cloud lines. Given the limited flight time compared with the C-130, the students decided that the King Air would only fly flight patterns designed for this first mission. Although not as well equipped to sample aerosols, it was believed that the King Air's instrumentation would provide beneficial ancillary support to the instruments on the C-130. It was decided to direct the two aircrafts to separate lines to avoid air traffic complications.

2) Structure and dynamics of island tail clouds: A cloud line frequently forms downstream of the island of Barbuda in midday (commonly referred to as a "tail cloud"). Tail clouds are common downstream of islands, but the students pointed out that almost nothing is known about their formation and maintenance. The proposed flight plan involved developing cross sections along the axis of the island of Barbuda (normal to the cloud line axis) by flying at three elevations at five locations: 1) upstream of the island, 2) over the island, 3) just downwind through the cloud line, 4) several kilometers downwind, and 5) far downwind but still across the cloud line. Following these cross sections, the C-130 would fly along the tail at three elevations. The students noted that on several of the days prior to the student flight, an island tail was not present. Taking this into consideration, alternative plans were discussed in case an island tail failed to develop.

3) Aerosol structure along a trajectory near the ground aerosol measurement tower at Dian Point on Antigua: Several students were involved in aerosol sampling at Dian Point on Antigua. Other than the ferry flights at the beginning and end of the RICO campaign, no aircraft measurements had been planned in the vicinity of the surface sampling site. The students proposed an intercomparison mission with the C-130 flying a pass $100 \mathrm{~m}$ above the site following takeoff from Antigua's Robert Bird International Airport and passes at 100 and $500 \mathrm{~m}$ above the site on its return to the airport.

Based on the C-130 and King Air flight schedules during RICO, possible dates for the student flight (18 or 19 January) were selected about a week in advance. The students submitted their final proposal to the project organizers on the morning of 17 January. They argued that all three $\mathrm{C}-130$ missions could be carried out within the 8-h C-130 window, dedicating $3 \mathrm{~h}$ to mission 1 and $3 \mathrm{~h}$ to mission 2 . The remaining time would be dedicated to standard project circle patterns when dropsondes would be launched and low-level aerosol sampling would be conducted. Mission 3 would be part of the ferries out and back between Antigua and the primary research areas over the ocean. The plan was approved and the students presented the plan to project scientists that same afternoon.

Previously, students submitted their preferred operations position to the student principal investigators. Luckily, there was little overlap in position preference, so every student ended up with the position that he/she wanted. Given the limited lead time, everything had to be in place prior to the proposal presentation, including moving students in charge of radar and rawinsondes operations to the other island, Barbuda.

The student mission was carried out on 18 January 2005. The role of the mission scientist on the C-130 was split between two students, one for each of the first two missions. Students carried out key tasks on the C-130, including dropsonde launches and operation of key instrumentation. Professor Rauber and NCAR scientists Jorgen Jensen and David Rogers provided guidance to students on the $\mathrm{C}-130$ during the flight but left on-the-fly decision making to 
the students as the mission evolved. A student also served as mission scientist on the King Air. On the ground, students served as flight coordinators, radar scientists, rawinsonde launchers, and in all other key positions normally occupied by project scientists. Project scientists remained available for questions throughout the mission but left decision making to the students. With plans ready and students in position, the flights commenced.

The C-130 flight started with the intercomparison leg over the aerosol ground site. However, on the ferry out to the operations area, it appeared that the clouds were not cooperating. A stratus deck was present, which threatened to limit convection. The student mission scientist stuck with the initial plan, which was to fly a circle at $4200 \mathrm{~m}$ dropping dropsondes and then to descend to $500 \mathrm{~m}$ and fly a circle for aerosol measurements. Due to the precipitating stratus deck and relatively pristine atmosphere below it, it was decided to skip the 100-m circle. Instead, a 5-min flight leg was flown in the clear area upwind of the stratus deck at $100 \mathrm{~m}$ followed by a brief leg at $350 \mathrm{~m}$ to take a sample with the Giant Aerosol Impactor. During the circles, students used radio communications and chat lines between the operations center, the aircraft, and the radar to find an appropriate cloud line for the first objective. Plans were still being discussed as the $100-\mathrm{m}$ flight leg was nearing completion. With five minutes left, the operations center student scientists typed a message stating that a cloud line was developing northeast of the aircraft position (Fig. 1). The flight scientist

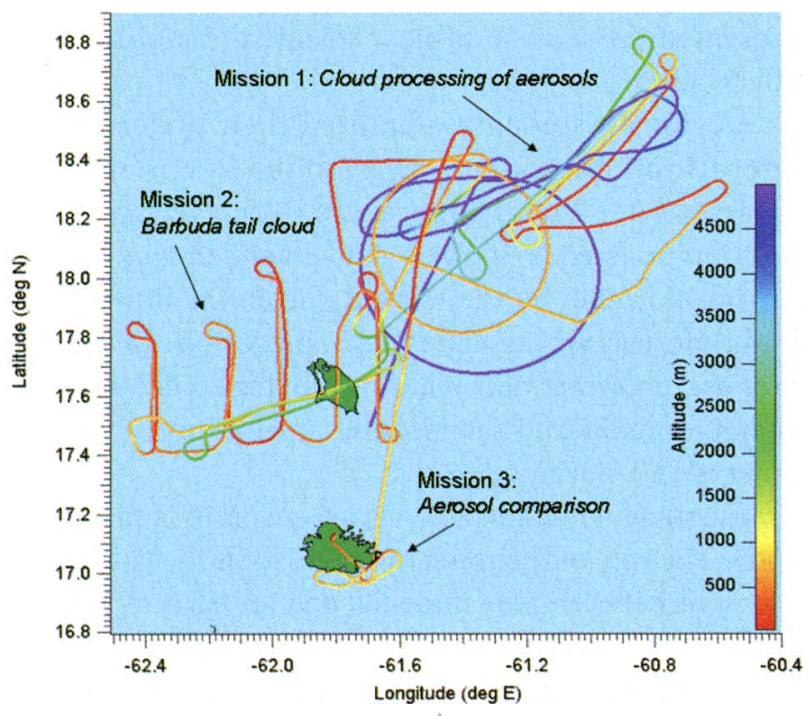

FIG. I. Flight track of the NSF/NCAR C-I 30 during the student flight. The flight originated in Antigua (lower island) with operations northeast and west of Barbuda (upper island). directed the aircraft to the line and carried out the aerosol-sampling mission according to the preconceived flight plan. The King Air also successfully carried out its flight plan in another cloud line.

During the aerosol sampling, a cloud tail was not present downwind of Barbuda. A decision had to be made in flight whether or not to continue the first mission at the midflight point or to begin studying the tail cloud. This decision was complicated by a stratus deck, which obscured any possible island tail from the satellite's field of view. During the latter part of the first mission, the radar coordinator reported that a tail cloud might be developing but could not confirm it. It was decided in flight to attempt the tail cloud study anyway, so following the aerosol sampling, the second mission scientist took over direction of the aircraft. By the time the aircraft arrived near Barbuda, it was visually clear from the cockpit that Barbuda's tail cloud was well developed. The second mission was also successfully carried out according to plan (Fig. 1). During the tail cloud sampling, the students documented a never before reported phenomenon-a funnel cloud emerging from one of the convective cells along the tail (Fig. 2). The flight was completed with a second round of intercomparisons over the aerosol site on Antigua. The students accomplished each mission, a remarkable success particularly with the complications the stratus layer presented during the flight.

The student mission was not the only opportunity students had to fly on the C-130. Every student who wanted to fly on the C-130 was given the opportunity on at least one research flight. Several students flew on multiple flights, taking responsibility for the operation of specific instruments provided by their home institutions. The students were never just passengers; they were given the chance to operate various instruments and even help the mission scientists make decisions in the cockpit as opportunities developed to conduct specific missions during the flights.

ROCKIN' ON THE HIGH SEAS: EDUCATION ON THE RVSJ. The Research Vessel Seward Johnson (RVSJ) would have been a shell of a ship-based research platform without the fortitude of its students. The ship left Ft. Pierce, Florida, on 29 December for Barbuda. En route, high seas and near engine failure gave the students an unplanned adventure-keeping a lookout for pirates in the dark of night while the crew made engine repairs off of the coast of Haiti-a rite of passage mentioned in everyone's graduate student handbook! After a port call for a more thorough 
engine repair in Puerto Rico, the ship eventually arrived on site on 5 January. While fighting seasickness in the perpetually high seas off Barbuda, students launched rawinsondes, kept the radars and remote sensors running, and analyzed each day's data (Fig. 3). During the ship's port call on 15 January, all of the project students on Antigua visited the ship and were instructed on the operation of each of the ship's instruments. For the final leg of the research voyage, the students were joined by Judith Malley, a teacher from Clague Middle School in Ann Arbor, Michigan. Her participation was made possible through the University of Colorado's Teacher-at-Sea program.

The educational experience on the ship differed from the land-based experience. One fundamental difference is time; time slows down on a ship, creating both opportunities and challenges. Opportunities include longer discussions with scientists and engineers than may be likely to occur on land. There are student opportunities to learn more about instrument behavior than may be possible with more sophisticated aircraft instrumentation. Certainly, the student experience of the diurnal cycle is more complete than is likely to occur on land. Time is available for personal projects that otherwise one may feel too busy for while on land. The challenge, of course, is to use the ship time constructively. Seasickness and boredom were a common experience. During RICO, the unanticipated failure of one of the cloud radars led to inactivity, as there were few other projects on the ship with which the students could become involved. Nevertheless, the initial preparation for the experiment, the ship experience, and the subsequent data analysis provided a unique experience for those students taking on the high seas.

MILES FROM NOWHERE: THE BARBUDA

EXPERIENCE. Barbuda, a small Caribbean island with an airstrip, intermittent ferry service, and fewer than 500 permanent residents, was the home of the

S-band and K-band dual-polarization (S-PolKa) Doppler radars and the project's ground-based rawinsonde launch site (Fig. 4). Most students participating in RICO spent at least 2-3 days on Barbuda working with radar scientists and launching rawinsondes. Several students whose graduate research involved radar analysis spent much longer periods. While at the radar, students were directly involved in field operations. S-PolKa scientists and engineers took time during the visits to teach students the basics of radar technology and meteorology. A highlight for many students was the rawinsonde launch adventure.

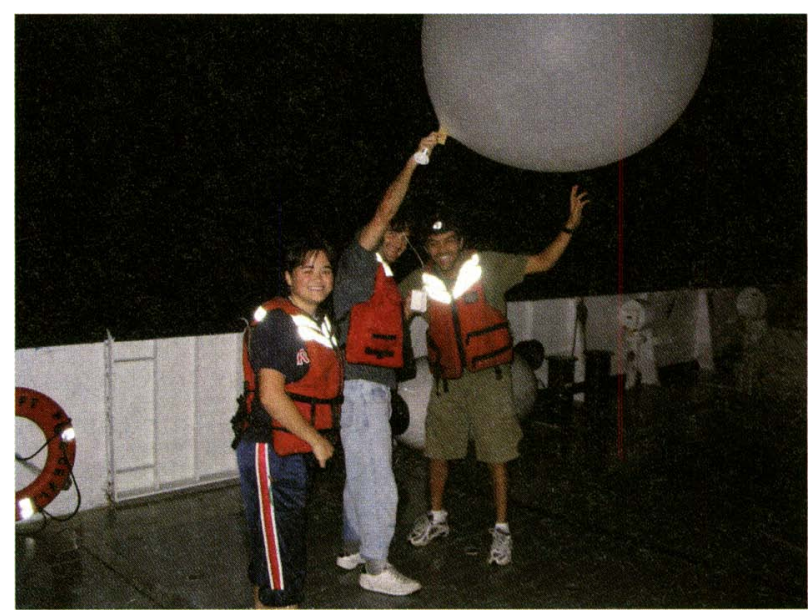

FIG. 3. Students Kristen Rasmussen, leng Jo, and Virendra Ghate launching a rawinsonde in the middle of the night from the deck of the RVSJ. 


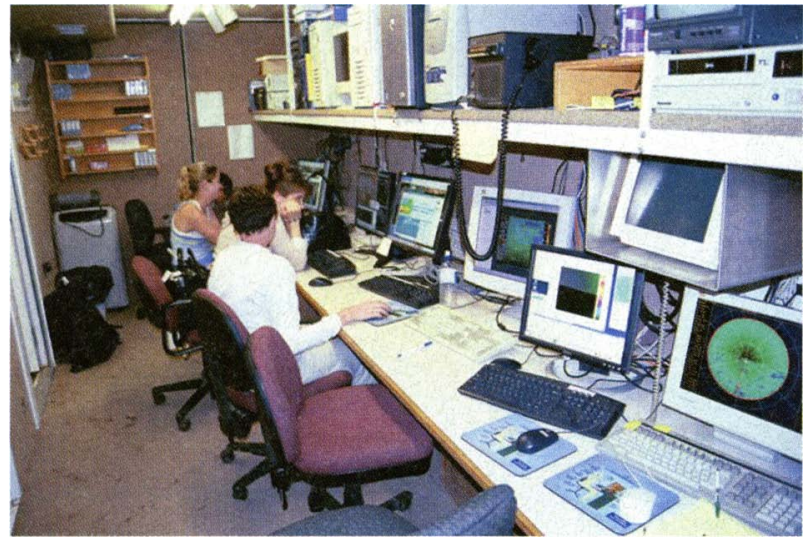

Fig. 4. Students Ela Grzeszczak, Colleen Henry, and Eric Snodgrass working with Research Scientist Sabine Göke in the NCAR S-PolKa radar van.

To reach the launch site, the launch team embarked on a 45 -min drive in a four-wheel-drive vehicle down a poorly maintained road that was a favorite resting spot for cows, donkeys, and goats. Launches were made from the island tip, where the Caribbean Sea meets the Atlantic. The visits to Barbuda were also a cultural opportunity, a rare chance to get to know Caribbean life far away from the typical tourist experience. The people of Barbuda were particularly helpful and friendly-in their words "Ya man, no problem!"

\section{CLIMBING THE TOWER-AEROSOL SAMPLING ON ANTIGUA (DIAN POINT).}

Dian Point, located at the far northeastern point of the island of Antigua, was the site of ground-based aerosol measurements taken during December 2004 and January 2005. A $10-\mathrm{m}$ scaffolding tower and trailer were used to deploy the instruments. Students were in charge of most of the measurements at this location. A suite of instruments to measure aerosol properties was located in the trailer, while a sky camera and a ceilometer were located nearby.

In preparation for the tasks required at Dian Point, students from the University of Puerto Rico underwent an intensive training phase in the atmospheric chemistry laboratory at the University of Puerto Rico-San Piedras (UPR-RP) from June to November 2004. They learned how to use the instrumentation and were trained in analytical techniques, such as thermal/optical analysis and total organic carbon analysis, which were to be used for the chemical characterization of the collected aerosol samples after the campaign. They also learned how to assure quality control and participated in a short pre-RICO sampling period to ensure they were prepared.
A typical day began with students traveling $45 \mathrm{~min}$ to Dian Point, arriving around 7 A.M., checking all instruments in the trailer to ensure they were working properly, checking the weather station, downloading weather data, and preparing materials needed for the most adventurous work-climbing the tower! (Fig. 5). At the top of the tower, they changed the filters/substrates for the filter samplers and the low pressure impactor, and then descended the tower to store filters and substrates in a freezer. The work of these dedicated students did not end after the field campaign. Once back at UPR-RP, they began chemical analyses of the samples. After a year and a half, nearly all the samples and data have been analyzed.

\section{PREDICTING THE FUTURE-THE RICO}

FORECASTING TEAM. A team of students managed the project forecast operations during RICO. The lead forecaster during the December period was a graduate student. During part of the period, he worked with a forecaster from the Caribbean Institute of Meteorology on the island of Barbados. During the January period, teams of students worked on preparing forecasts under the guidance of project scientists. The students quickly

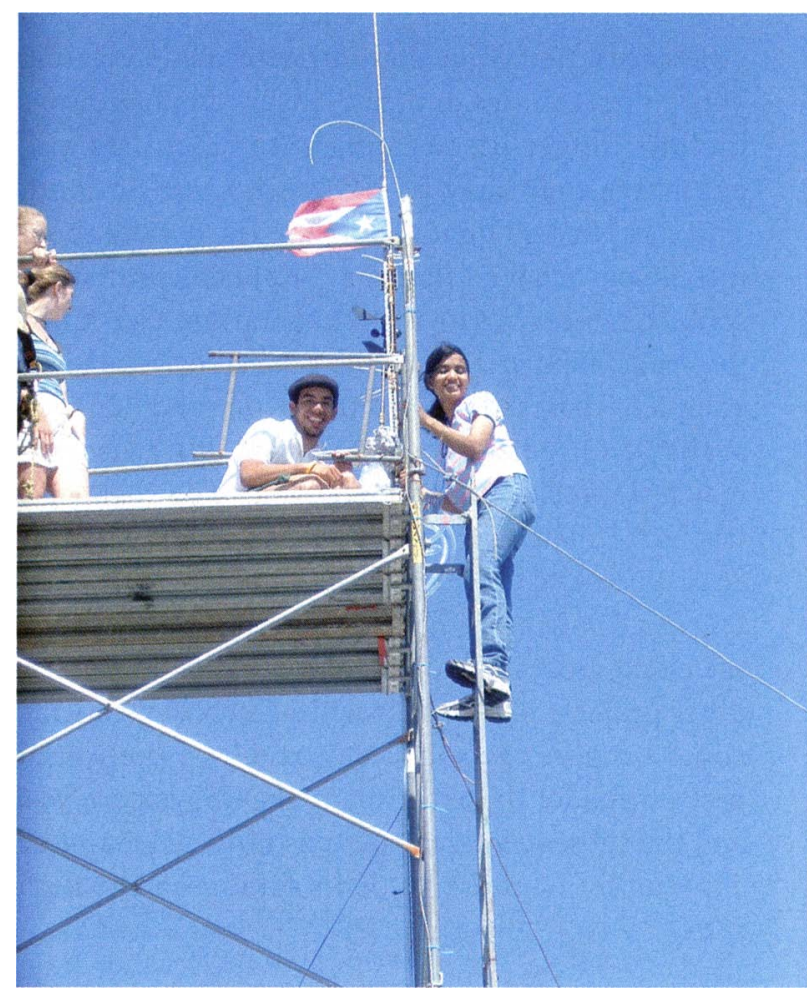

FIG. 5. Student Humberto Caro-Gautier explaining the instrumentation to fellow students Subhashree Mishra, Jennifer Small, and Jennifer Davison on the aerosol tower at Dian Point. 
developed specific products and procedures that were best suited to flight planning, occasionally led forecast discussions at the daily planning meetings, prepared flight weather briefings prior to each flight, and contributed to postflight debriefings after flight operations (Fig. 6).

\section{HEARING FROM THE EXPERTS-THE} RICO SEMINAR SERIES. RICO provided a unique opportunity for students to be mentored by a wide range of experts. To facilitate understanding of the project goals, a seminar series was arranged for the January portion of the experiment when most students would be present (Table 1). The schedule was set up prior to going into the field, so that scientists had adequate time to prepare their presentations. The seminars began with a general introduction to the trade wind region and covered all the major research themes of RICO. Many scientists were able to incorporate RICO datasets into their talks. Seminars were held in the operations center and were recorded using the recording tools available in Microsoft PowerPoint. Subsequent to the RICO campaign, the seminars were posted online and are available for download (see www.eol.ucar.edu/rico/). In total, 12 seminars were given during the field campaign. In addition, talks were given at the C-130 and the other aircraft to take advantage of proximity to the instrumentation, and at the RVSJ during a port call on 15 January.

OUTREACH TO THE ISLANDS. The RICO campaign was an unusual event on the islands, so much so that the installation of the S-PolKa radar

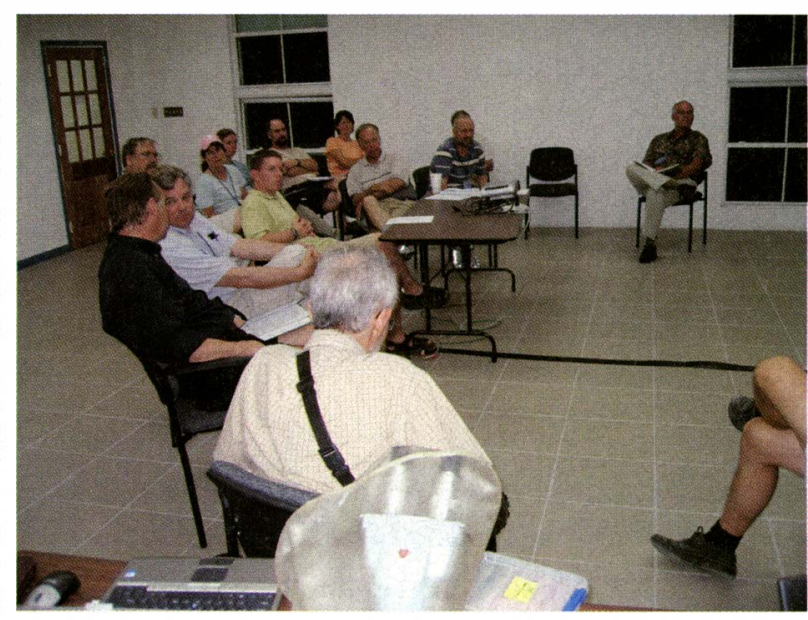

FIG. 6. Student forecaster Michael Kruk (in green shirt) leading a preflight briefing prior to a C-I30 flight.

on Barbuda was first thought by local residents to be a Central Intelligence Agency (CIA) operation! One goal in RICO was to give local students the opportunity to see firsthand the meteorological equipment used in weather research. Students were particularly interested because they have all experienced and continually live under the threat of hurricanes. RICO investigators invited local high school teachers to bring students for a tour of the NSF/ NCAR C-130 research aircraft, where they learned about the instrumentation, the flight patterns, and why Antigua's trade wind cumulus clouds are so well suited for the research. At the radar, middle school children from the Holy Trinity School on the island of Barbuda visited and watched a demonstration of a rawinsonde launch (Fig. 7). This excursion was part of their science class and the children were assigned

\begin{tabular}{|l|l|}
\hline \multicolumn{2}{|l|}{ TABLE I. Seminars given during the RICO campaign. } \\
\hline Speaker & Topic \\
\hline Bjorn Stevens & Structure of the trade wind layer \\
\hline Sonia Lasher-TrapP & The warm-rain process \\
\hline A. Pier Siebesma & Dynamics of shallow cumulus convection and its representation in large-scale models \\
\hline Cindy Twohy & Marine aerosols, clouds, and climate \\
\hline Hermann Gerber & Liquid water content in cumulus \\
\hline Bart Geerts & Radar fundamentals \\
\hline Bill Cotton & Aerosols, clouds, and precipitation \\
\hline Jim Anderson & Characterizing atmospheric aerosols with electron beam instruments \\
\hline Jorgen Jensen & Sea salt and warm rain-From observation to modeling \\
\hline Charles Knight & $Z_{\text {DR }}$ and precipitation \\
\hline Dan O'Sullivan & Hydrogen peroxide and methylhydroperoxide measurements in RICO \\
\hline Don Thornton & Sulfur gas chemistry, cloud condensation nuclei (CCN), and clouds \\
\hline
\end{tabular}




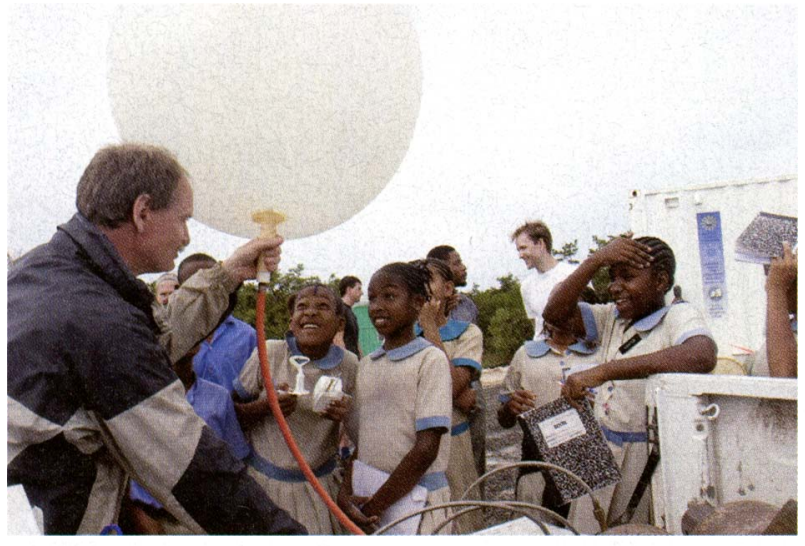

Fig. 7. NCAR scientist Steve Oncley explaining how a rawinsonde operates to middle school students on Barbuda during RICO.

to write a report summarizing their experience. The visit lasted over $2 \mathrm{~h}$ and ended with a bus getting stuck in the mud (pulled out by well-trained NCAR radar engineers!).

PUBLICATIONS: STUDENTS TAKE THE LEAD. Students wrote the first two publications describing RICO. Shortly after RICO, Louise Nuijens, a graduate student from the University of Wageningen in the Netherlands, published "The hunt for cumulus during RICO" in the Dutch publication Meteorologica (Nuijens 2005). Sarah Scalia, an undergraduate student at the University of Illinois at UrbanaChampaign, published an article in Weatherwise, "A break in the clouds," describing her experience in RICO (Scalia 2006). Graduate students who participated in RICO presented posters at the 2005 American Geophysical Union (AGU) conference and the 2006 American Meteorological Society (AMS) cloud physics conference describing the RICO student mission and its preliminary findings (Small et al. 2005; Davison et al. 2006). The UPR-RP undergraduate students completed their projects, after which they presented their results at the minisymposium for an audience of students and professors from different campuses as well as nonscientist observers. Many student participants in RICO attended the 2005 AMS radar conference and the 2006 AMS cloud physics conference, as well as several American Geophysical Union meetings. The first refereed publications emerging from RICO were lead-authored by students (Zhao and Di Girolamo 2006; Colón-Robles et al. 2006; Zhao and Di Girolamo 2007). Many student at the participating institutions are basing their Master's theses and doctoral dissertations on data collected in RICO and are preparing manuscripts for publication. In addition, several students are now conducting modeling studies using RICO data as a basis for model validation.

SUMMARY. The purpose of this article, in addition to describing the educational component of RICO, is to serve as a template for the integration of education into field campaigns of the future. It is appropriate, therefore, to consider improvements that could be made. In RICO, the primary goal was to provide a wide variety of educational activities to students during the field campaign. By all measures, this aspect of the campaign was a success. However, the organizers did not develop a clear strategy for postproject collaborative student activities. The student flight presented an opportunity for students from many campuses to collaborate on a focused data analysis. With the wealth of new data from RICO, demands for research advances related to the specific grants of their mentors, and the demands to complete their own theses and dissertations, this collaborative activity did not occur. The students did come together to present a paper on the student flight at a scientific conference, but no refereed article has yet emerged as a group project. Analyses of the student missions are indeed occurring and will be done, but as efforts of individual students rather than the group as a whole. In future projects, planners should consider mechanisms for continued collaboration once the students return to their home institutions.

One of the greatest contributions any field campaign can make to the advancement of science is inspiring future generations of scientists to pursue careers in our field. Field campaigns provide a unique opportunity to bring true excitement to education. In RICO, we explored new ways to integrate research and education within the framework of a field campaign. New approaches, such as the student mission and the RICO seminar series, demonstrate that education can be deeply integrated into field research. We hope that the experiences in RICO summarized in these pages will encourage future field studies to incorporate a wide array of educational activities into the field experience.

ACKNOWLEDGMENTS. Funding for graduate student participation in RICO was provided by the National Science Foundation under Grants NSF-ATM0346172, ATM-0336849, ATM-0342623, ATM-034258, ATM-0342421, ATM-0342618, ATM-0342597, ATM0342623, ATM-034258, ATM-0342651, and ATM-0526600. Undergraduates participating in RICO were funded by the NSF Research Experiences for Undergraduates Program under Grants NSF-ATM-0346172, ATM-0342623, and 
ATM-034258. Funding for participation of middle school teacher Judy Malley was supported by the NSF under Grant NSF-ATM-0342623, which contained a partnership with Dr. Susan Buhr and Genevieve Healy of the Cooperative Institute for Research in Environmental Sciences (CIRES) Outreach program. The authors thank the many scientists and staff of the National Center for Atmospheric Research for all their efforts in the field mentoring students. Any opinions, findings, and conclusions are those of the authors and do not necessarily reflect the views of the National Science Foundation or the Illinois State Water Survey.

\section{REFERENCES}

Borys, R. D., and M. A. Wetzel, 1997: Storm Peak Laboratory: A research, teaching and service facility for the atmospheric sciences. Bull. Amer. Meteor. Soc., 78, 2115-2123.

Colón-Robles, M., R. M. Rauber, and J. B. Jensen, 2006: Influence of low-level wind speed on droplet spectra near cloud base in trade wind cumulus. Geophys. Res. Lett., 33, L20814, doi:10.1029/2006GL027487.

Davison, J. L., and Coauthors, 2006: The RICO student mission-Flights, ground operations and subsequent research. Preprints, 12th Conf. on Cloud Physics, Madison, WI, Amer. Meteor. Soc., CD-ROM, P2.27.

Fabry, F., B. J. Turner, and S. A. Cohn, 1995: The University of Wyoming King Air educational initiative at McGill University, Bull. Amer. Meteor. Soc., 76, 1806-1811.

Hallett, J., J. G. Hudson, and A. Schanot, 1990: Student training in facilities in atmospheric sciences: A teaching experiment. Bull. Amer. Meteor. Soc., 71, 1637-1644.
_, M. Wetzel, and S. Rutledge, 1993: Field training in radar meteorology. Bull. Amer. Meteor. Soc., 74, 17-22.

Nuijens, L., 2005: The hunt for cumulus during RICO (in Dutch). Meteorologica, 1, 19-22.

Rauber, R. M., and Coauthors, 2007: Rain in shallow cumulus over the ocean-The RICO campaign. Bull. Amer. Meteor. Soc., 88, 1912-1928.

Scalia, S., 2006: A break in the clouds. Weatherwise, 59, 43-47.

Small, J. D., S. D. Anderson-Bereznicki, B. Medeiros, L. Nuijens, C. K. Henry, D. M. O’Donnell Jr., and F. Morales, 2005: RICO graduate student research flight: The island tail objective. Extended Abstracts, Amer. Geophys. Union Fall Meeting Suppl., Abstract ED33A-1235, San Francisco, CA, Amer. Geophys. Union.

Stith, J. L., and D. C. Rogers, 2004: Instrument development and education in airborne science. Preprints, 13th Symp. on Education, Seattle, WA, Amer. Meteor. Soc., CD-ROM, 4.12.

Wetzel, M. A., R. D. Borys, and D. R. Lowenthal, 2003: Graduate field training in atmospheric measurements. Preprints, 12th Symp. on Education, Long Beach, CA, Amer. Meteor. Soc., CD-ROM, 5.10.

Zhao, G., and L. Di Girolamo, 2006: Cloud fraction errors for trade wind cumuli from EOS-Terra instruments. Geophys. Res. Lett., 33, L20802, doi:10.1029/ 2006 GL027088.

—, and — 2007: Statistics on the macrophysical properties of trade wind cumuli over the tropical western Atlantic. J. Geophys. Res., 112, D10204, doi:10.1029/2006JD007371.

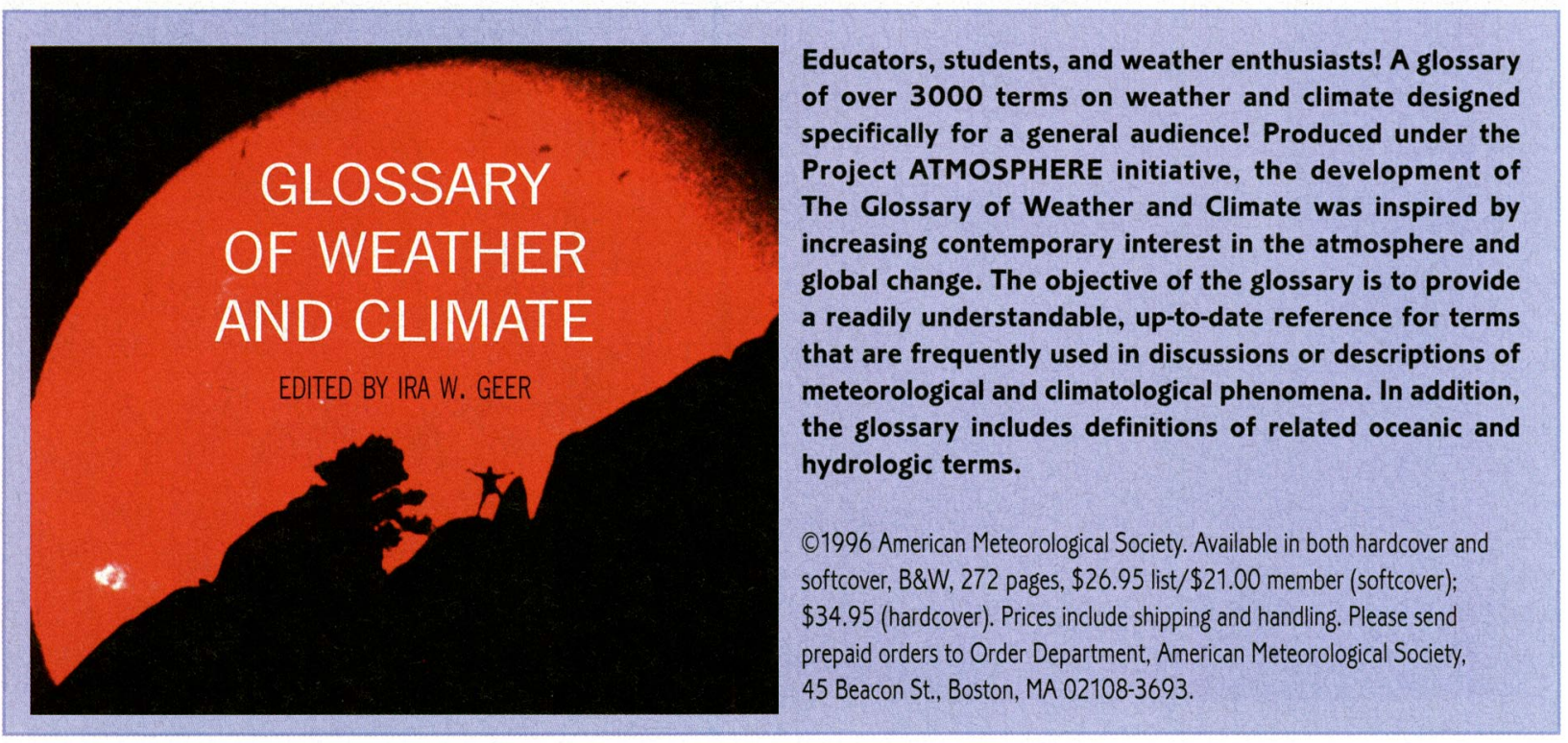




\section{Immense yourself in Washingtor, DC}

\section{AYIS SUMMYIER POLICY \\ coLLOQUIUTMI \\ JUNNE 1-10, 2008}

- Intieract \& network with Federal, Congressional, and other leaders in the science policy arena Acquaint yourself with the policy process - Build your skills and experience, for effective - participation in the policy arena - Develop your leadership potential

\section{Who Should Aftend}

- Aspiring leaders in government, industry, and academia

- University faculty \& research staff

- Graduate students accepted on the basis of a national competition

- Faculty at minority-serving institutions (financial support available) 